\title{
Research Article \\ Effect of Perovskite Film Preparation on Performance of Solar Cells
}

\author{
Yaxian Pei, Xiaoping Zou, Xiaolei Qi, Gongqing Teng, Qi Li, \\ Dongdong Guo, and Shuangxiong Zeng
}

\begin{abstract}
Research Center for Sensor Technology, Beijing Key Laboratory for Sensor, Ministry of Education Key Laboratory for Modern Measurement and Control Technology, School of Applied Sciences, Beijing Information Science and Technology University, Jianxiangqiao Campus, Beijing 100101, China
\end{abstract}

Correspondence should be addressed to Xiaoping Zou; xpzou2014@163.com

Received 25 March 2016; Accepted 23 May 2016

Academic Editor: Javeed Akhtar

Copyright (C) 2016 Yaxian Pei et al. This is an open access article distributed under the Creative Commons Attribution License, which permits unrestricted use, distribution, and reproduction in any medium, provided the original work is properly cited.

For the perovskite solar cells (PSCs), the performance of the PSCs has become the focus of the research by improving the crystallization and morphology of the perovskite absorption layer. In this thesis, based on the structure of mesoporous perovskite solar cells (MPSCs), we designed the experiments to improve the photovoltaic performance of the PSCs by improved processing technique, which mainly includes the following two aspects. Before spin-coating $\mathrm{PbI}_{2}$ solution, we control the substrate temperature to modify the crystal quality and morphology of perovskite films. On the other hand, before annealing, we keep $\mathrm{PbI}_{2}$ films for the different drying time at room temperature to optimize films morphology. In our trials, it was found that the substrate temperature is more important in determining the photovoltaic performance than drying time. These results indicate that the crystallization and morphology of perovskite films affect the absorption intensity and obviously influence the short circuit current density of MPSCs. Utilizing films prepared by mentioning two methods, MPSCs with maximum power conversion efficiency of over $4 \%$ were fabricated for the active area of $0.5 \times 0.5 \mathrm{~cm}^{2}$.

\section{Introduction}

In recent years, the remarkable improvements in the crystallization and morphology of the perovskite absorption layer have resulted in rapidly improving the power conversion efficiency (PCE) of PSCs. Nevertheless, thin film morphology still has a huge limitation to improve the PCE of the PSCs. If the perovskite thin film is not uniform, pin-holes exist, which are quite easy to cause the short circuit of solar cells. Initially, utilizing films fabricated by one-step spin-coating method, the perovskite grains are large, but the film surface is rough [1]. Therefore, the group of Kim et al. first reported that the perovskite thin films were prepared by two-step sequential deposition method. Using this technique, the reproducibility of perovskite greatly increases. And they achieved a PCE of approximately 15\% [2]. Liu et al. reported the PCE of $15.4 \%$ from a planar heterojunction perovskite solar cell, which are attributed to the extremely uniform flat films deposited by vapor deposition method [3]. The thin film morphology is extremely easy to be controlled. However, vapor deposition remarkably raises the cost of fabrication. The morphology of the perovskite film is highly sensitive to the synthesis conditions and processes, such as the choice of precursors, annealing temperatures, and preheating substrate. It was reported that adding $\mathrm{PbCl}_{2}$ to the precursor solution could control the morphology of perovskites, leading to an increase of the PCE of PSCs [4-6]. In addition, Dualeh et al. researched the effect of annealing temperature on film morphology of PSCs, which obtained the best PCE of $11.66 \%$ [7]. Recently, an ultra-smooth perovskite thin film with high crystallinity was obtained by mixed-solvent vapor annealing at room temperature and the PCE of $16.4 \%$ [8]. In 2015, Ko et al. reported the PCE up to $15.76 \%$ by preheating substrate temperatures from $40^{\circ} \mathrm{C}$ to $60^{\circ} \mathrm{C}$ to change the perovskite absorption layer [9]. Therefore, the film crystallization and morphology are crucial to obtaining high-performance solar cells in the present study.

In order to investigate the performance of the PSCs by improving the film crystallization and morphology, before spin-coating $\mathrm{PbI}_{2}$ solution, we present a strategy that the 
substrate was preheated at temperatures ranging from room temperature to $100^{\circ} \mathrm{C}$ to optimize the quality of the perovskite film. On the other hand, on the basis of the optimal preheating temperature, the formed $\mathrm{PbI}_{2}$ substrates are dried at room temperature for different drying time ranging from $0 \mathrm{~min}$ to $30 \mathrm{~min}$ to fabricate the perovskite thin film. These two methods lead to improve the absorption intensity and obviously increase the current density in MPSCs without any modification. The maximum efficiency is up to $4.23 \%$. The entire fabrication processes of perovskite solar cells were carried out under the humidity about $30 \%$ and outside the glove box.

\section{Experimental and Methods}

2.1. Materials. Unless otherwise stated, all materials were purchased from Sinopharm Chemical Reagent Beijing Co., Ltd., or Shanghai MaterWin New Materials Co., Ltd., and used as received. Co(III) PF6 Spiro (Spiro-OMeTAD) solution was purchased from Beijing Huamin New Materials Technology Co., Ltd.

2.2. Device Fabrication. The fluorine-doped tin oxide (FTO) conductive glasses were cleaned by ultrasonic in detergent, rinsed with deionized water, followed by washing with the mixture of deionized water, ethanol, and acetone at $1: 1: 1$ by volume, and suffered from $\mathrm{O}_{3}$ /ultraviolet treatment for one hour. The $\mathrm{TiO}_{2}$ blocking $\left(\mathrm{bl}-\mathrm{TiO}_{2}\right)$ underlayer was deposited on the cleaned FTO conductive glasses by spin-coating method at $2000 \mathrm{rpm}$ for $30 \mathrm{~s}$ and heated at $120^{\circ} \mathrm{C}$ for $10 \mathrm{~min}$ and then sintered at $500^{\circ} \mathrm{C}$ for $30 \mathrm{~min}$. Then $\mathrm{TiO}_{2}$ paste was diluted by ethanol at 1:3.5 by weight and deposited on the top of the bl- $\mathrm{TiO}_{2} / \mathrm{FTO}$ substrates by spin-coating at $3000 \mathrm{rpm}$ for $30 \mathrm{~s}$ and sintered at $500^{\circ} \mathrm{C}$ for $30 \mathrm{~min}$ to form mesoporous $\mathrm{TiO}_{2}\left(\mathrm{mp}-\mathrm{TiO}_{2}\right)$ layer.

In our trials, we carried out the following two steps. (1) The FTO/bl-TiO $/ \mathrm{mp}_{2} \mathrm{TiO}_{2}$ substrates were preheated at $30^{\circ} \mathrm{C}, 50^{\circ} \mathrm{C}, 70^{\circ} \mathrm{C}$, and $100^{\circ} \mathrm{C}$ on a hot plate for $15 \mathrm{~min}$, respectively. The $\mathrm{PbI}_{2}(1 \mathrm{~mol} / \mathrm{L})$ solution which was stirred for one hour at $70^{\circ} \mathrm{C}$ was deposited on the $\mathrm{mp}-\mathrm{TiO}_{2}$ film at $5500 \mathrm{rpm}$ for $15 \mathrm{~s}$, followed by thermal annealing at $100^{\circ} \mathrm{C}$ for $30 \mathrm{~min}$ on hot plate to form a stable film. The $\mathrm{PbI}_{2}$ solution was kept at $70^{\circ} \mathrm{C}$ while spin-coating. (2) On the basis of the preheating substrate temperature, we adopted the optimum temperature. Under the temperature, the formed $\mathrm{PbI}_{2}$ films were dried at room temperature for $0 \mathrm{~min}, 5 \mathrm{~min}, 10 \mathrm{~min}$, $20 \mathrm{~min}$, and $30 \mathrm{~min}$, followed by thermal annealing at $100^{\circ} \mathrm{C}$ for $30 \mathrm{~min}$.

The methylammonium iodide (MAI $10 \mathrm{mg} / \mathrm{mL}$ ) was spincoated on top of the $\mathrm{PbI}_{2}$ film layers at $0 \mathrm{rpm}$ (under stationary condition) for $10 \mathrm{~s}$, followed by $3000 \mathrm{rpm}$ for $30 \mathrm{~s}$, which was dried at $100^{\circ} \mathrm{C}$ for $30 \mathrm{~min}$. The Spiro-OMeTAD solution was deposited on top of the methylammonium lead iodide $\left(\mathrm{MAPbI}_{3}\right)$ films by spin-coating at $2000 \mathrm{rpm}$ for $30 \mathrm{~s}$. Finally, a candle burning method was used to prepare carbon electrode as counter electrode. The FTO-candle soot film was directly deposited by putting a cleaned FTO glass in the candle flame for about 3 seconds [10]. Then the FTO-candle soot film and the perovskite film were directly clamped to fabricate the solar cell.

2.3. Characterization. The current density-voltage $(J-V)$ curves were measured using a VersaSTAT3 source meter under standard air-mass 1.5 global (AM1.5G) illumination $\left(100 \mathrm{~mW} \cdot \mathrm{cm}^{-2}\right)$ provided by a solar simulator (Oriel Sol $3 \mathrm{~A})$. The surface morphology of thin films was observed by scanning electron microscopy (SEM). The SEM images were performed with an S-4300 (CARL ZEISS, Germany). Xray diffraction (XRD) was used to analyze the crystallinity and size of sample. The XRD measurement was performed with Bruker D8 focus (Bruker Corporation, Germany). The monochromatic incident photon-to-electron (IPCE) was measured with an IPCE measurement tool (Institute of Physics, CAS, China) in our laboratory.

\section{Results and Discussions}

3.1. Effect of Preheating the Substrate Temperature on the Performance of the MPSCs, before Spin-Coating $\mathrm{PbI}_{2}$ Solution. In this paper, we investigate the influence of the different preheating substrate temperatures (unheated, $30^{\circ} \mathrm{C}, 50^{\circ} \mathrm{C}$, $70^{\circ} \mathrm{C}$, and $100^{\circ} \mathrm{C}$ ) on the perovskite film layers before spincoating $\mathrm{PbI}_{2}$. The specific experiment average parameters and sample calibration used are presented in Table 1; H-RT represents the without preheated substrate, that is, at room temperature (RT), and $\mathrm{H}-30, \mathrm{H}-50, \mathrm{H}-70$, and $\mathrm{H}-100$ represent the preheating temperature of $30^{\circ} \mathrm{C}, 50^{\circ} \mathrm{C}, 70^{\circ} \mathrm{C}$, and $100^{\circ} \mathrm{C}$, respectively. Table 1 describes the average parameters on a batch of four photovoltaic devices, which are consistent with Figure 1.

Figure 1 presents the average distribution curves of the short circuit current density $\left(J_{\mathrm{sc}}\right)$, open circuit voltage $\left(V_{\mathrm{oc}}\right)$, fill factor (FF), and power conversion efficiency (PCE) as the preheating substrate temperature ranges from being unheated to $100^{\circ} \mathrm{C}$. Compared with nonpreheated substrate, the average $J_{\mathrm{sc}}$ and PCE have a significant improvement. However, the average $V_{\text {oc }}$ and FF are not strongly affected by the substrate temperature (Figure 1). As the preheating substrate temperature increases, the average $J_{\text {sc }}$ and PCE firstly increase and then decrease. Table 1 gives a clear correlation between the preheating substrate temperature of the perovskite and the photovoltaic performance of the devices. The range of average $J_{\mathrm{sc}}$ and PCE is from $7.04 \mathrm{~mA} / \mathrm{cm}^{2}$ to $8.53 \mathrm{~mA} / \mathrm{cm}^{2}$ and from $3.22 \%$ to $3.95 \%$, respectively. And the average $V_{\text {oc }}$ increases from $800 \mathrm{mV}$ to $950 \mathrm{mV}$. We obtain the average FF value of $46-60 \%$. When the substrate temperature reaches $70^{\circ} \mathrm{C}$, the maximum average value of $J_{\mathrm{sc}}$ is $8.53 \mathrm{~mA} / \mathrm{cm}^{2}$; as a result of the highest average PCE and $V_{\mathrm{oc}}$ are $3.95 \%$ and $892 \mathrm{mV}$, respectively. This may be attributed to the relative high light harvest efficiency [11]. However, when the temperature is $100^{\circ} \mathrm{C}$, the average $\mathrm{FF}$ runs up to the maximum value $(\mathrm{FF}=57 \%)$. Therefore, we can draw a conclusion that the optimal preheating temperature was around $70^{\circ} \mathrm{C}$ at least in our experimental procedure.

The effect of the preheating substrate temperature on the morphology and crystallinity of the $\mathrm{PbI}_{2}$ films and the 


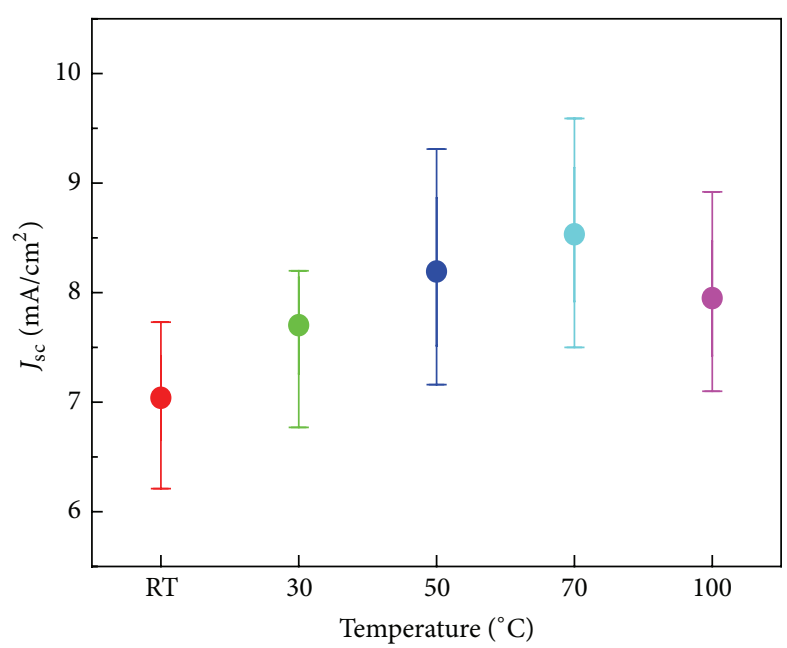

(a)

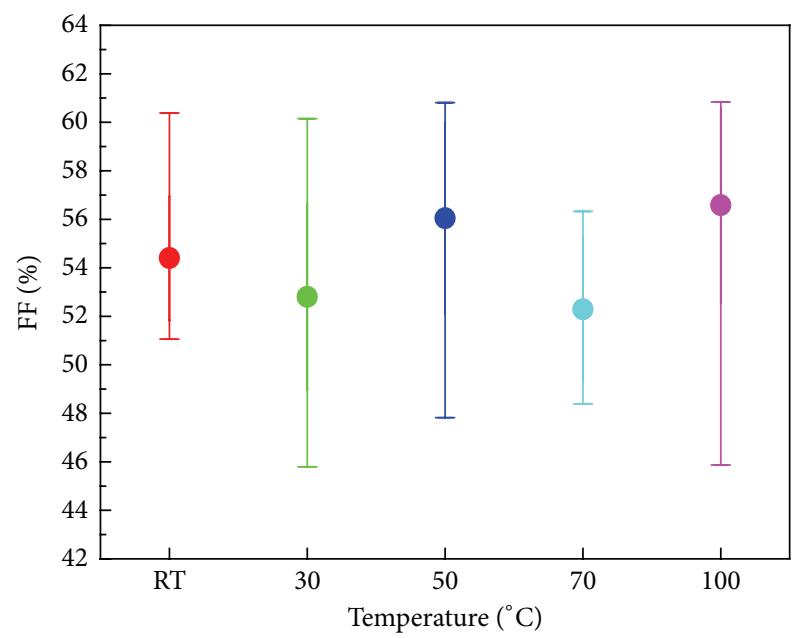

(c)

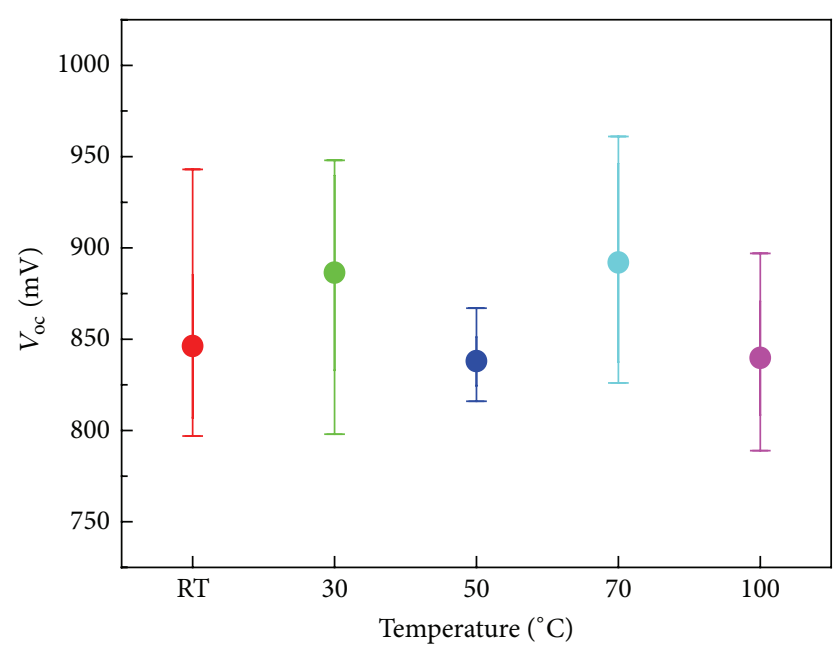

(b)

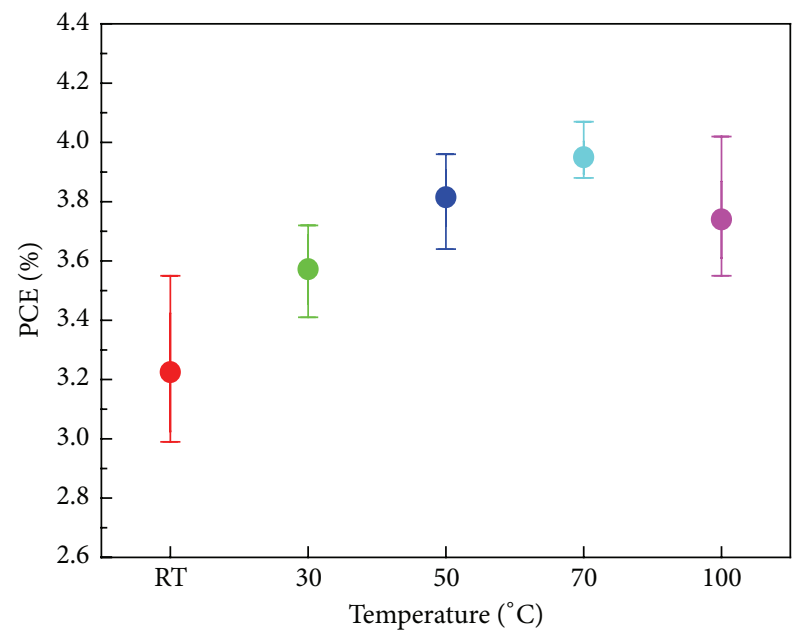

(d)

FIGURE 1: $J-V$ characteristics of MPSCs based on $\mathrm{MAPbI}_{3}$ perovskite thin films depending on the different preheating substrate, before spin-coating $\mathrm{PbI}_{2}$ solution: (a) short circuit current density $\left(J_{\mathrm{sc}}\right)$, (b) open circuit voltage $\left(V_{\mathrm{oc}}\right)$, (c) fill factor (FF), and (d) power conversion efficiency (PCE).

TABLE 1: Experiment average parameters and sample calibration of different substrate temperature.

\begin{tabular}{lcccc}
\hline Preheating temperature $J_{\mathrm{sc}}\left(\mathrm{mA} / \mathrm{cm}^{2}\right)$ & $V_{\mathrm{oc}}(\mathrm{mV})$ & $\mathrm{FF}(\%)$ & $\eta(\%)$ \\
\hline H-RT & 7.04 & 846 & 54.40 & 3.22 \\
H-30 & 7.70 & 886 & 52.80 & 3.57 \\
H-50 & 8.19 & 838 & 56.06 & 3.81 \\
H-70 & 8.53 & 892 & 52.29 & 3.95 \\
H-100 & 7.95 & 840 & 56.58 & 3.74 \\
\hline
\end{tabular}

perovskite layers were measured by SEM (Figure 2). As the preheating substrate temperature increased, there is a severe change in the appearance of the films. By comparison, the $\mathrm{PbI}_{2}$ film of without preheating substrate does not completely cover the $\mathrm{mp}-\mathrm{TiO}_{2}$ substrate (Figure 2(a)), while the $\mathrm{PbI}_{2}$ film of preheating substrate is better coverage. At the same time, the morphology of $\mathrm{PbI}_{2}$ formed at $50^{\circ} \mathrm{C}$ is extremely uniform and complete coverage, which is relatively similar in appearance to that formed at $70^{\circ} \mathrm{C}$ (Figures 2(c) and 2(d)). Furthermore, the gaps between the $\mathrm{PbI}_{2}$ crystallites are slightly small in the case of $70^{\circ} \mathrm{C}$. Increasing the preheating substrate temperature up to $100^{\circ} \mathrm{C}$, the morphology of $\mathrm{PbI}_{2}$ is relatively homogeneous, but there are still $\mathrm{TiO}_{2}$ nanoparticle on the surface of $\mathrm{PbI}_{2}$ (Figure 2(e)). The reasons for the different $\mathrm{PbI}_{2}$ morphology are that the crystallization rate of $\mathrm{PbI}_{2}$ becomes higher than the solvent evaporation rate as the preheating substrate temperature increases [8]. Therefore, the preheating substrate is beneficial to promoting the crystallization rate of $\mathrm{PbI}_{2}$ and obtaining the more uniform and denser film morphology. In addition, after forming the $\mathrm{MAPbI}_{3}$ films, the cuboids $\mathrm{MAPbI}_{3}$ crystals are closely packed as the preheating substrate temperature increases. It is noted that the $\mathrm{MAPbI}_{3}$ grains size also increases with the 


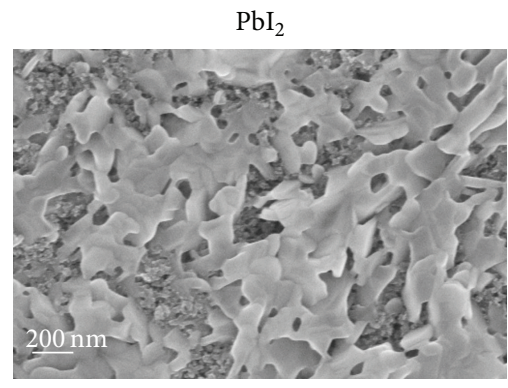

(a)

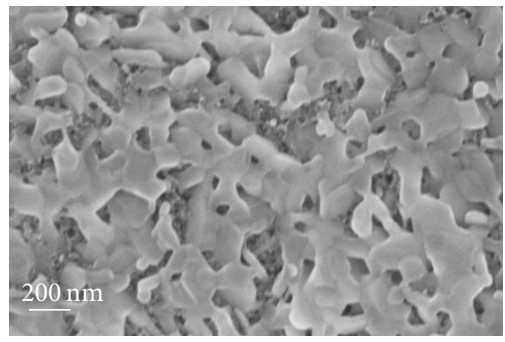

(b)

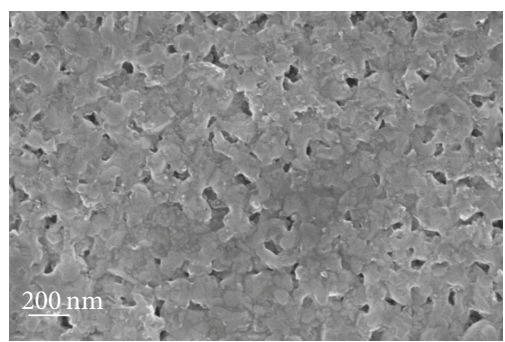

(c)

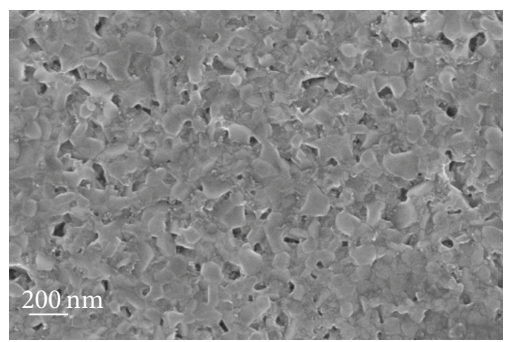

(d)

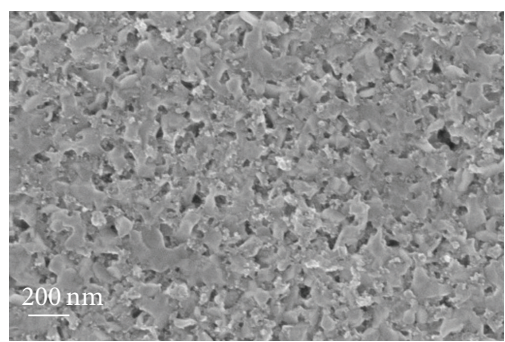

(e)

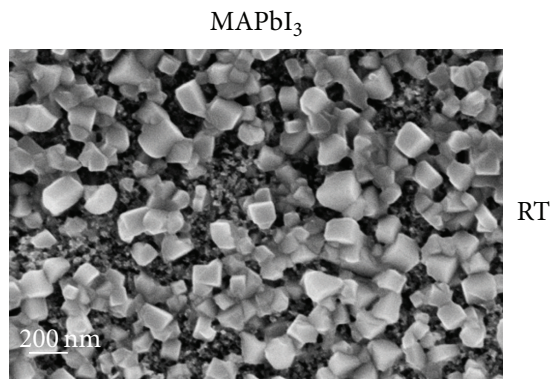

(f)

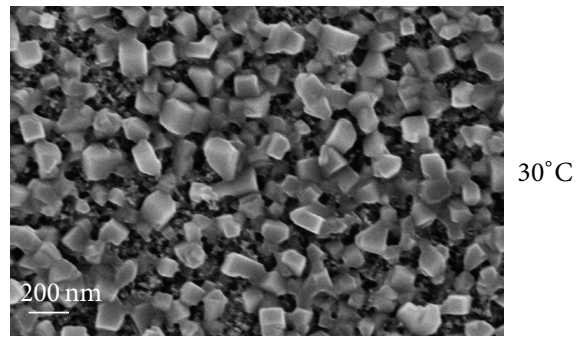

(g)

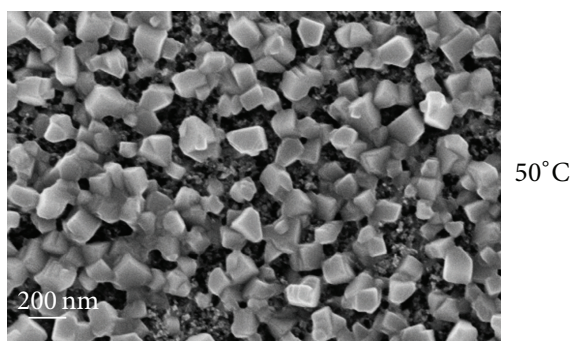

(h)

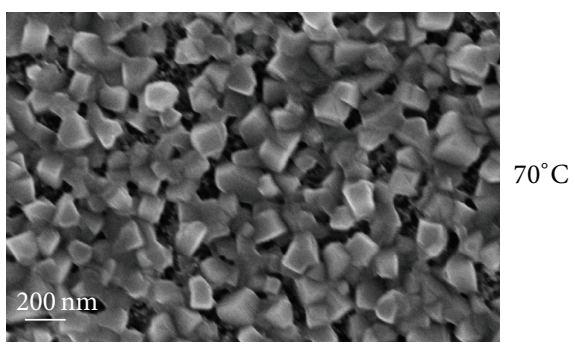

(i)

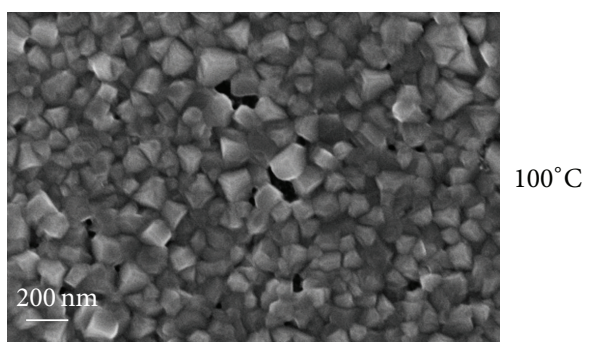

(j)

FIgURE 2: Top-view SEM images of the $\mathrm{PbI}_{2}$ layers deposited on the $\mathrm{mp}-\mathrm{TiO}_{2}$ coated $\mathrm{FTO}$ substrate, where the substrate was preheated at (a) RT (without preheating), (b) $30^{\circ} \mathrm{C}$, (c) $50^{\circ} \mathrm{C}$, (d) $70^{\circ} \mathrm{C}$, and (e) $100^{\circ} \mathrm{C}$. The $\mathrm{MAPbI}_{3}$ thin film layers (f-j) correspond to the $\mathrm{PbI}_{2}$ layers deposited on the different preheating substrate. 
preheating temperature increasing (Figures $2(f)-2(j)$ ), which is related to the conversion rate of $\mathrm{PbI}_{2}$ to $\mathrm{MAPbI}_{3}$. In other words, the coverage rate of the $\mathrm{PbI}_{2}$ film and the perovskite film become better as the preheating temperature increases. Therefore, it is conductive to avoid the direct contact between the electron transport layer and the hole transport layer, so as to reduce the recombination of electrons and holes.

Here we also show cross-sectional SEM images of the $\mathrm{PbI}_{2}$ films and $\mathrm{MAPbI}_{3}$ films without preheating and preheating at $70^{\circ} \mathrm{C}$ (Figure 3 ). The $\mathrm{PbI}_{2}$ is smoothly deposited on nonpreheated substrate (Figure 3(a)). However, a part of $\mathrm{PbI}_{2}$ is loaded into the mesopores of $\mathrm{mp}-\mathrm{TiO}_{2}$ film at $70^{\circ} \mathrm{C}$ (Figure 3(b)), which is beneficial to forming the perovskite layer. It is also found that amount of perovskite is effectively infiltrated into the mesopores of $\mathrm{mp}-\mathrm{TiO}_{2}$ film upon preheating the substrate at $70^{\circ} \mathrm{C}$ compared to the nonpreheated substrate (Figures $3(\mathrm{c})$ and $3(\mathrm{~d})$ ), which increases the effective separation of electrons and holes and improves the PCE. In addition, considerable volume expansion occurs in the sequential deposition process based on $\mathrm{PbI}_{2}$; this can be attributed to the insertion of MAI into $\mathrm{PbI}_{2}$ skeleton [12]. It is noted that the thickness of perovskite film significantly increases in Figure 3(d), which is advantageous to the generation of photo-induced carriers.

To further take consideration into the perovskite crystallinity depending on the preheating temperature, we analyze the performance of the $\mathrm{PbI}_{2}$ films deposited on the preheating substrate by XRD measure (Figure 4). From the XRD spectrum, the $\mathrm{PbI}_{2}$ peak at $12.67^{\circ}$ is suitable to the (001) lattice plane. As a comparison, the full width at half maximum (FWHM) of $\mathrm{PbI}_{2}$ films becomes narrow and the $\mathrm{PbI}_{2}$ peak intensity increases with the increasing in preheating substrate temperature. The results indicate that the peak intensity is higher, and the crystallinity of $\mathrm{PbI}_{2}$ film is better, as the preheating temperature increases.

We also give the characteristics of the $\mathrm{MAPbI}_{3}$ films formed following the preheating substrate by XRD measure (Figure 5). As shown in Figure 5, the $\mathrm{MAPbI}_{3}$ peak at $14.19^{\circ}$ is assigned to the (110) lattice plane. By comparison, as the preheating substrate temperature increases, the intensity of the $\mathrm{MAPbI}_{3}$ (110) peak increases, which is attributed to increasing the conversion rate of perovskite [7]. Moreover, the $\mathrm{PbI}_{2}$ peak appears, and the peak intensity increases due to the enhanced crystallinity of $\mathrm{PbI}_{2}$ with the preheating temperature increasing. The results lead to the residual $\mathrm{PbI}_{2}$ conversion fully into the $\mathrm{MAPbI}_{3}$ for a long time. But when the preheating substrate temperature is up to $70^{\circ} \mathrm{C}$, the peak for the $\mathrm{PbI}_{2}$ is absent and only the peak for the perovskite material remains. It is consistent with the statistics result of MPSCs performance.

\subsection{Effect of the Drying Time at Room Temperature on the} Performance of MPSCs, after Spin-Coating the $\mathrm{PbI}_{2}$ Solution. Since the crystallinity of $\mathrm{PbI}_{2}$ and $\mathrm{MAPbI}_{3}$ films could be changed not only by the preheating substrate temperature but also by the drying time, we further investigate the effect of different drying time on MPSCs fabricated at $70^{\circ} \mathrm{C}$. Figure 6 shows the distribution curve of $J_{\mathrm{sc}}, V_{\mathrm{oc}}$, FF, and PCE
TABLE 2: Experiment average parameters and sample calibration of different drying time.

\begin{tabular}{lcccc}
\hline $\begin{array}{l}\text { Sample } \\
\text { drying time }\end{array}$ & $J_{\text {sc }}\left(\mathrm{mA} / \mathrm{cm}^{2}\right)$ & $V_{\text {oc }}(\mathrm{mV})$ & $\mathrm{FF}(\%)$ & $\eta(\%)$ \\
\hline$T-0$ min & 7.86 & 886 & 54.92 & 3.80 \\
$T-5$ min & 8.29 & 850 & 54.89 & 3.84 \\
$T-10 \mathrm{~min}$ & 8.84 & 885 & 52.21 & 4.03 \\
$T-20 \mathrm{~min}$ & 8.23 & 845 & 56.07 & 3.87 \\
$T-30 \mathrm{~min}$ & 8.13 & 870 & 52.02 & 3.65 \\
\hline
\end{tabular}

depending on different drying time $(0 \mathrm{~min}, 5 \mathrm{~min}, 10 \mathrm{~min}$, $20 \mathrm{~min}$, and $30 \mathrm{~min}$ ). The specific average parameters on a batch of four photovoltaic devices and sample calibration used are illustrated in Table 2, which correspond to Figure 6. As shown in Figure 6, the average $J_{\mathrm{sc}}$ and PCE firstly increase and then decrease, as the drying time increases. However, the average $V_{\mathrm{oc}}$ and $\mathrm{FF}$ are almost unaffected. When $\mathrm{PbI}_{2}$ films are dried at room temperature for $10 \mathrm{~min}$, the average $J_{\mathrm{sc}}$ and PCE reach the maximum value of $8.84 \mathrm{~mA} / \mathrm{cm}^{2}$ and $4.23 \%$, respectively. The average $V_{\mathrm{oc}}$ and $\mathrm{FF}$ range from $800 \mathrm{mV}$ to $900 \mathrm{mV}$ and from $50 \%$ to $60 \%$. These results clearly state that increasing drying time results in higher current density and efficiency at proper range.

We show the top-view SEM images of $\mathrm{PbI}_{2}$ films, which are dried for different time at room temperature (Figures $7(\mathrm{a})-7(\mathrm{e})$ ). As a comparison, the $\mathrm{PbI}_{2}$ grains size enlarges and the number of pores between $\mathrm{PbI}_{2}$ crystals increases, which depend on the different drying time ranging from $0 \mathrm{~min}$ to $10 \mathrm{~min}$. The results can easily bring MAI infiltrated into the gaps of $\mathrm{PbI}_{2}$ particles. It is advantageous to form the $\mathrm{MAPbI}_{3}$ films and promote the growth of the $\mathrm{MAPbI}_{3}$ grains. However, the surface of $\mathrm{PbI}_{2}$ films is obviously rough for $20 \mathrm{~min}$ and $30 \mathrm{~min}$. We present the SEM images of $\mathrm{MAPbI}_{3}$ films after spin-coating MAI (Figures 7(f)-7(j)). In comparison, the $\mathrm{MAPbI}_{3}$ grains size slightly increases, and the gaps of $\mathrm{MAPbI}_{3}$ grains become closely packed. The $\mathrm{MAPbI}_{3}$ grains are relatively compact for $5 \mathrm{~min}$ and $10 \mathrm{~min}$ (Figures $7(\mathrm{~g}$ ) and $7(\mathrm{~h})$ ). However, although the $\mathrm{MAPbI}_{3}$ films are dense for $30 \mathrm{~min}$, the PCE is quite low. It is attributed that the larger $\mathrm{MAPbI}_{3}$ particles size can lead to producing the pores of the $\mathrm{MAPbI}_{3}$ films [13]. The results indicate that the proper size of $\mathrm{MAPbI}_{3}$ particles can reduce the defects of films, which is beneficial to the effective separation and diffusion of carriers.

Next, we analyze the XRD patterns of the $\mathrm{PbI}_{2}$ and $\mathrm{MAPbI}_{3}$ thin film depending on the different drying time (Figures 8 and 9). As the drying time increases, the FWHM of $\mathrm{PbI}_{2}$ turns slightly narrow (Figure 8). This indicates that the drying time can promote the $\mathrm{PbI}_{2}$ grains slightly enlarging. However, at room temperature for a period of time, there is no apparent difference between the peaks of the $\mathrm{MAPbI}_{3}$ films depending on the different drying time (Figure 9). And it is observed that the $\mathrm{PbI}_{2}$ is almost complete conversion into the $\mathrm{MAPbI}_{3}$. Therefore, it is inferred that the preheating substrate temperature is more important than the drying time in the crystallinity of the $\mathrm{MAPbI}_{3}$. 


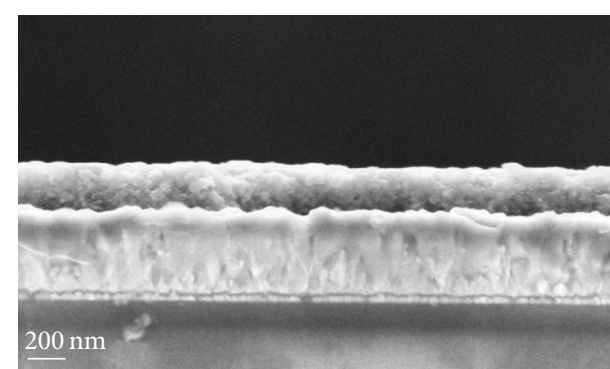

(a)

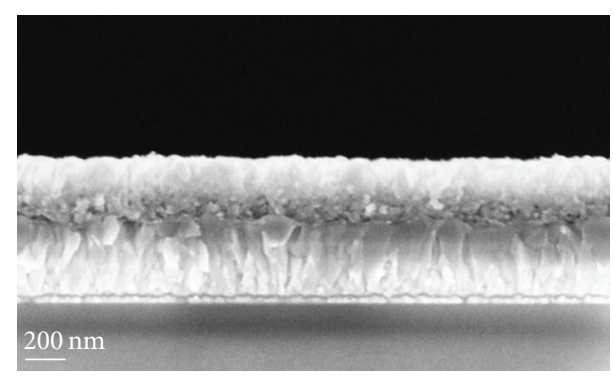

(c)

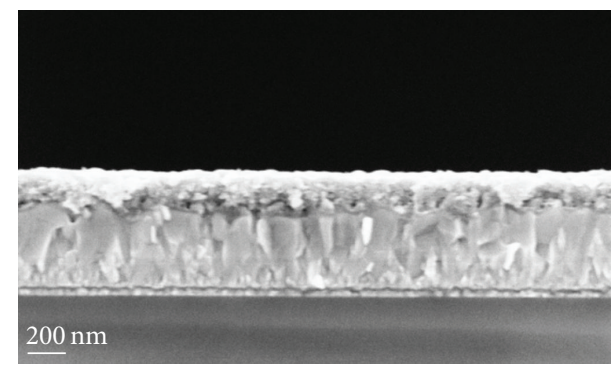

(b)

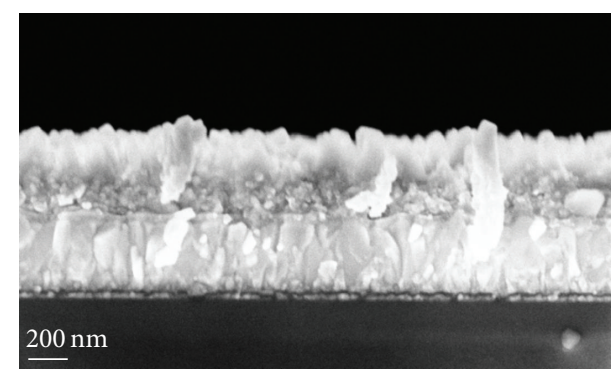

(d)

FIGURE 3: Cross-sectional SEM images of $\mathrm{PbI}_{2}$ layer deposited on the $\mathrm{mp}-\mathrm{TiO}_{2}$ coated FTO substrate, where the substrate was preheated at (a) room temperature and (b) $70^{\circ} \mathrm{C}$, and $\mathrm{MAPbI}_{3}$ films formed by deposition of $\mathrm{MAI}$ on the $\mathrm{PbI}_{2}$ layer were fabricated at substrate temperatures of (c) room temperature and $(\mathrm{d}) 70^{\circ} \mathrm{C}$.

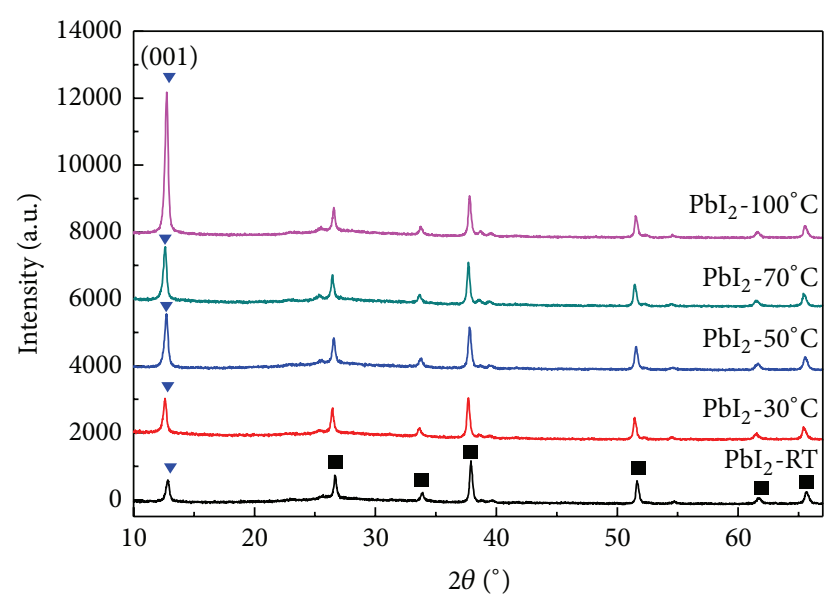

- FTO

$\checkmark \mathrm{PbI}_{2}$

FIGURE 4: XRD patterns of $\mathrm{PbI}_{2}$ films deposited on the different preheating substrate temperate of room temperature, $30^{\circ} \mathrm{C}, 50^{\circ} \mathrm{C}$, $70^{\circ} \mathrm{C}$, and $100^{\circ} \mathrm{C}$, respectively.

Figure 10 shows the optimum $J-V$ characteristics curves of MPSCs depending on the drying time of $0 \mathrm{~min}$ and $10 \mathrm{~min}$; Sample- $0 \mathrm{~min}$ and Sample-10 min represent the MPSCs depending on the drying time of $0 \mathrm{~min}$ and $10 \mathrm{~min}$, respectively. The specific photovoltaic performance parameters are provided in Table 3, which correspond to Figure 10. As shown in Figure 10, the performance of the Sample-10 min is higher than that of Sample- 0 min. The results are in agreement with

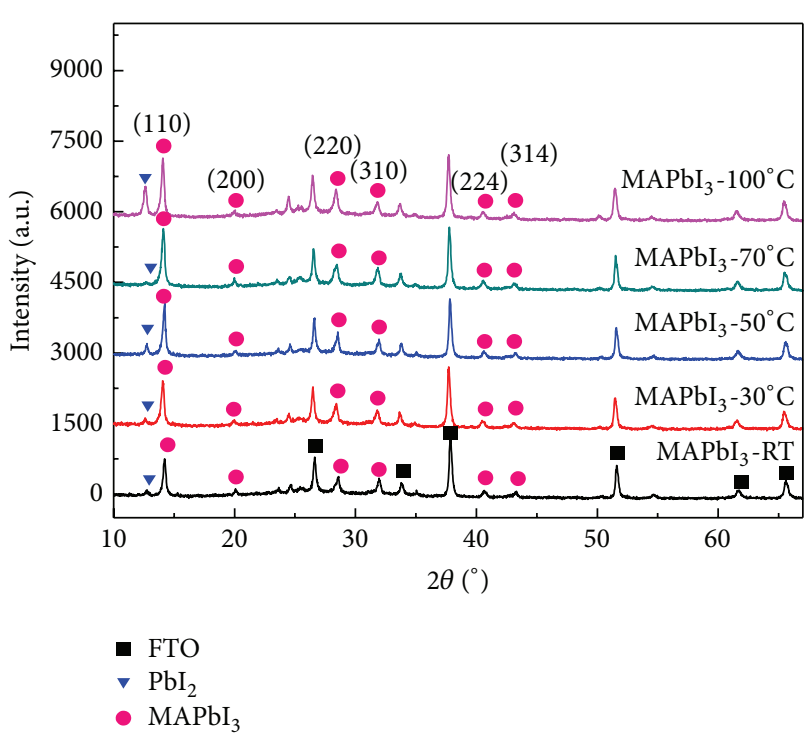

FIGURE 5: XRD patterns of $\mathrm{MAPbI}_{3}$ films, where MAI was deposited on the top of the $\mathrm{PbI}_{2}$ layers. The $\mathrm{MAPbI}_{3}$ films depended on the different preheating substrate temperature of room temperature, $30^{\circ} \mathrm{C}, 50^{\circ} \mathrm{C}, 70^{\circ} \mathrm{C}$, and $100^{\circ} \mathrm{C}$, respectively.

the statistics result of MPSCs performance. As illustrated in Table 3, the device with drying for 0 min presents $J_{\mathrm{sc}}$ of $8.7 \mathrm{~mA} / \mathrm{cm}^{2}, V_{\text {oc }}$ of $932 \mathrm{mV}$, and FF of $50.19 \%$, leading to an efficiency of $4.07 \%$. In the same batch, $J_{\mathrm{sc}}$ of $10.31 \mathrm{~mA} / \mathrm{cm}^{2}$, $V_{\mathrm{oc}}$ of $933 \mathrm{mV}, \mathrm{FF}$ of $43.97 \%$, and $\eta$ of $4.23 \%$ are obtained in the device with drying for $10 \mathrm{~min}$. 


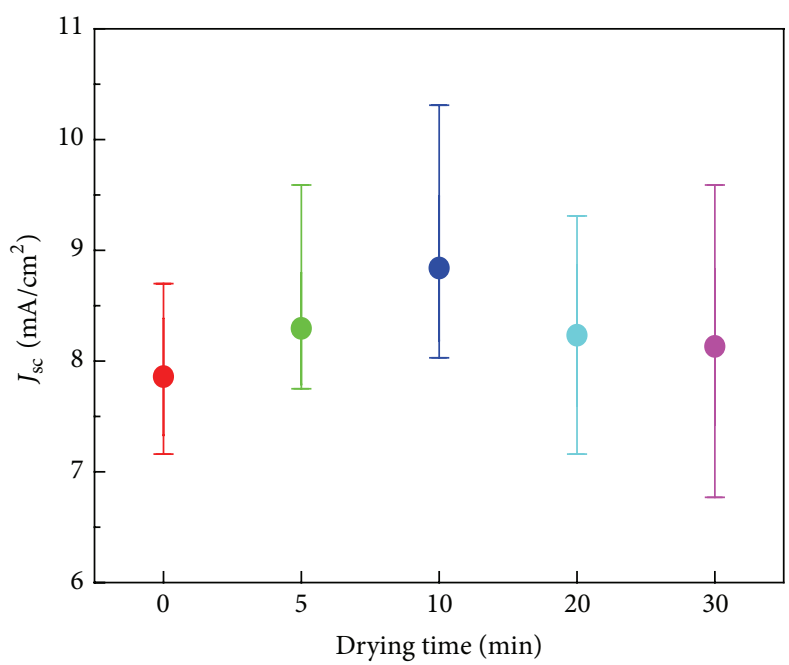

(a)

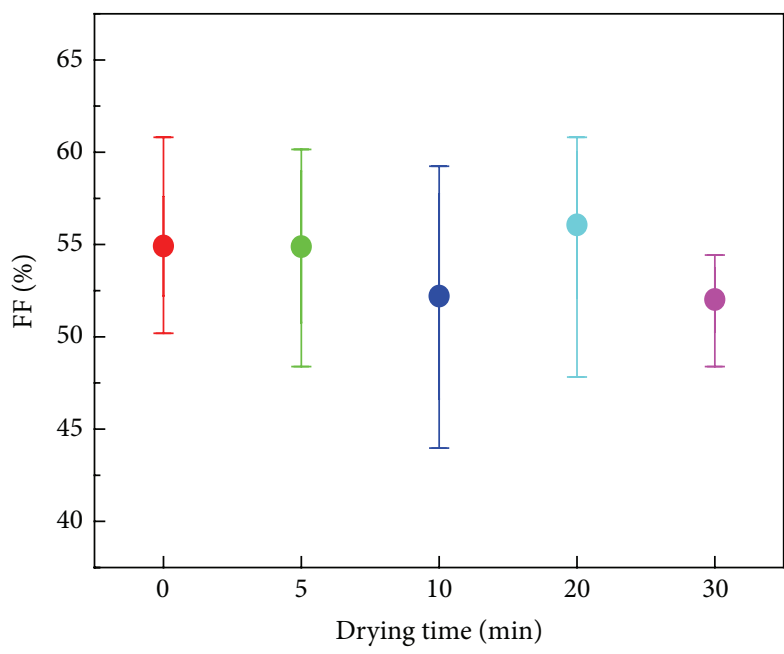

(c)

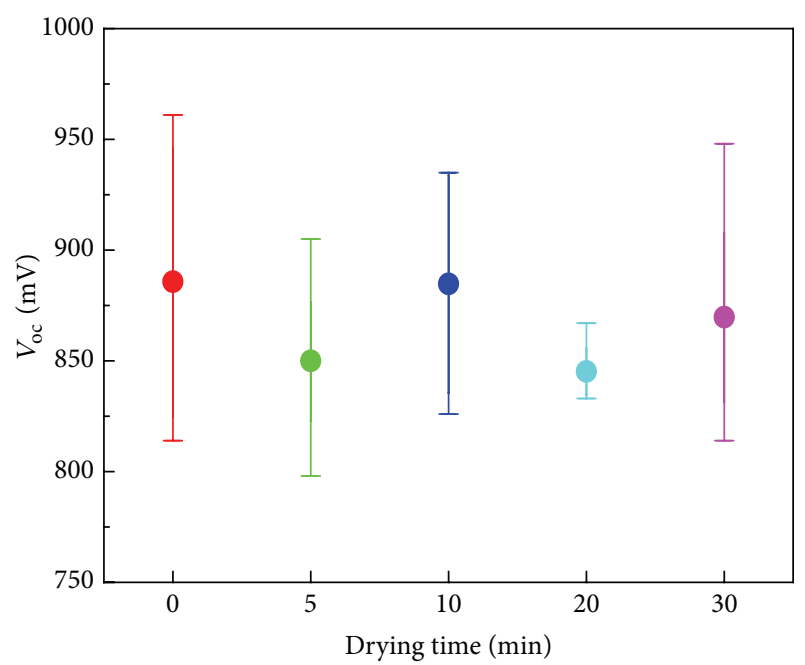

(b)

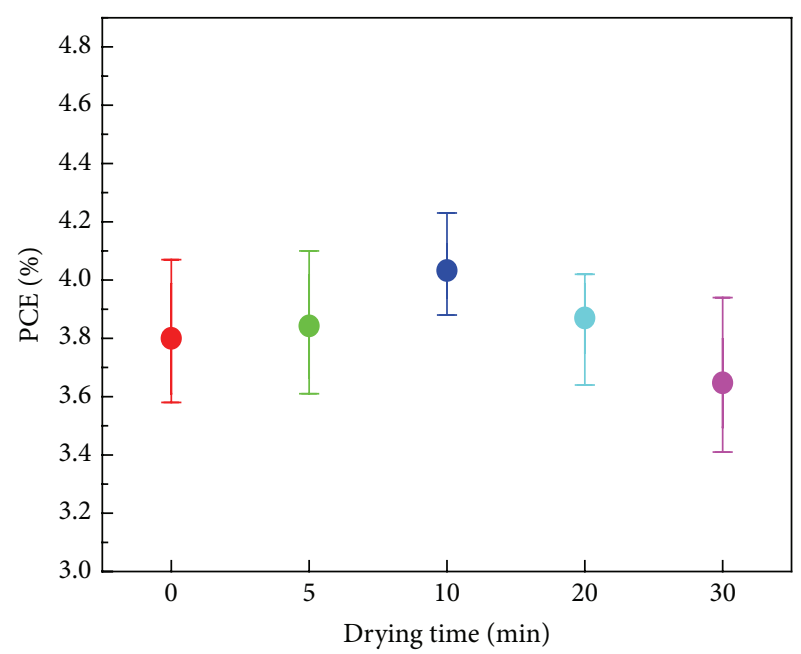

(d)

FIGURE 6: $J-V$ characteristics of MPSCs based on $\mathrm{MAPbI}_{3}$ perovskite thin films depending on the different drying time, after spin-coating $\mathrm{PbI}_{2}$ solution: (a) $J_{\mathrm{sc}}$, (b) $V_{\mathrm{oc}}$, (c) FF, and (d) PCE.

Moreover, we also present the curves of IPCE of MPSCs depending on the drying time of $0 \mathrm{~min}$ and $10 \mathrm{~min}$ (Figure 11). The value of IPCE improves about $10 \%$ between $400 \mathrm{~nm}$ and $750 \mathrm{~nm}$. As shown in Figure 11, $J_{\mathrm{sc}}$ is proved by IPCE measurement with an integrated $J_{\mathrm{sc}}$ of $8.5 \mathrm{~mA} / \mathrm{cm}^{2}$ and $10.1 \mathrm{~mA} / \mathrm{cm}^{2}$ depending on the drying time of $0 \mathrm{~min}$ and $10 \mathrm{~min}$, which is slightly lower than that derived from the $J-V$ measurement (Figure 10). In addition, we research the effect of drying time of $0 \mathrm{~min}$ and $10 \mathrm{~min}$ on the $J-V$ hysteresis. The typical $J-V$ characteristics curves depending on the drying time of $0 \mathrm{~min}$ and $10 \mathrm{~min}$ are conducted in both forward and backward direction at a scan rate of $0.1 \mathrm{~V} / \mathrm{s}$ (Figure 12). In terms of the scan direction, as a comparison, no significant $J-V$ hysteresis is observed in the device prepared for $10 \mathrm{~min}$, which may be associated with the large grain size of $\mathrm{MAPbI}_{3}$.
TABLE 3: Experiment parameters of the optimum MPSCs depending on the drying time of $0 \mathrm{~min}$ and $10 \mathrm{~min}$.

\begin{tabular}{lcccc}
\hline Sample & $J_{\text {sc }}\left(\mathrm{mA} / \mathrm{cm}^{2}\right)$ & $V_{\text {oc }}(\mathrm{mV})$ & $\mathrm{FF}(\%)$ & $\eta(\%)$ \\
\hline Sample-0 min & 8.70 & 932 & 50.19 & 4.07 \\
Sample-10 min & 10.31 & 933 & 43.97 & 4.23 \\
\hline
\end{tabular}

\section{Conclusions}

In summary, in our experiment, we investigated the role of the preheating substrate temperature and drying time for forming the perovskite layers. We can conclude that the preheated substrate led to the $\mathrm{PbI}_{2}$ infiltration into the $\mathrm{mp}$ $\mathrm{TiO}_{2}$ film and hence full coverage of the $\mathrm{TiO}_{2}$ film with 
$\mathrm{PbI}_{2}$

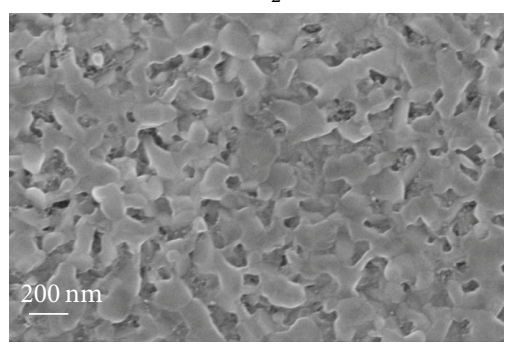

(a)

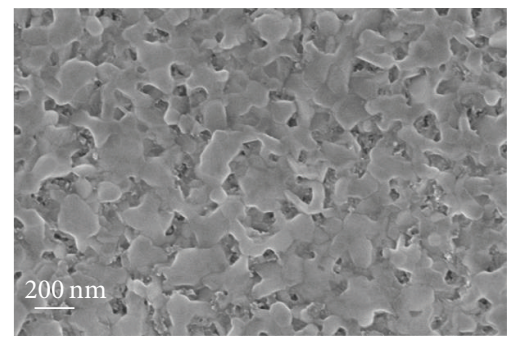

(b)

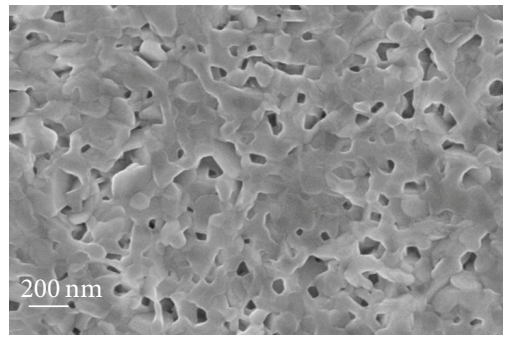

(c)

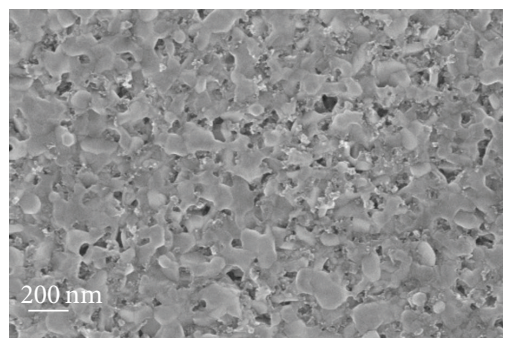

(d)

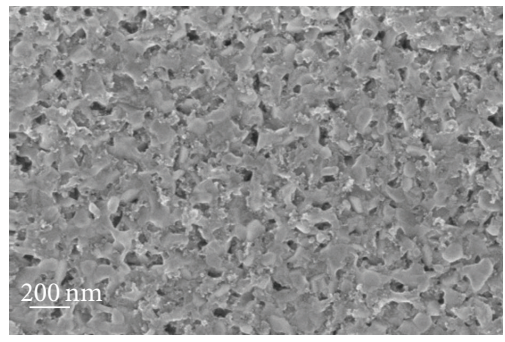

(e)

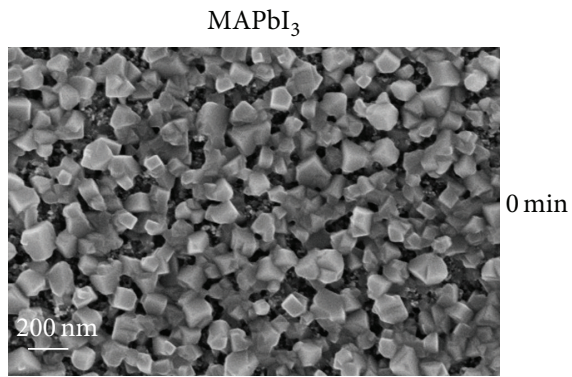

(f)

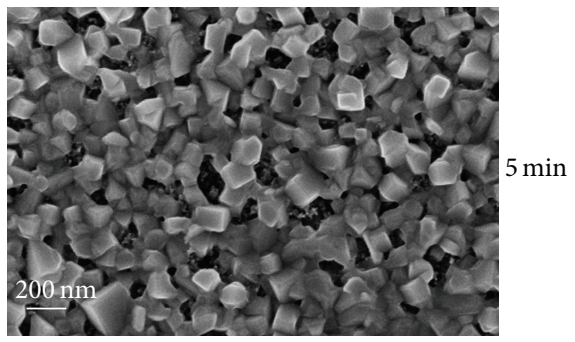

(g)

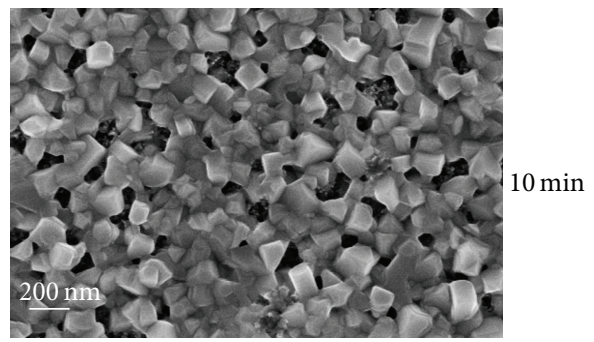

(h)

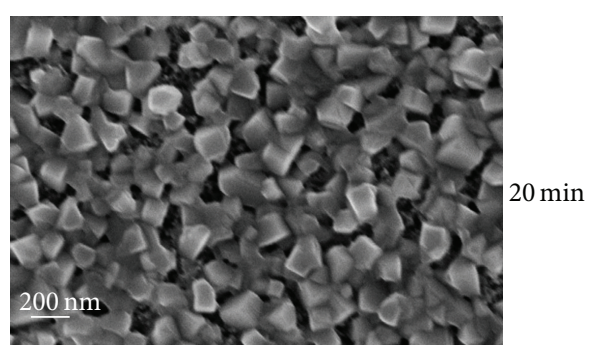

(i)

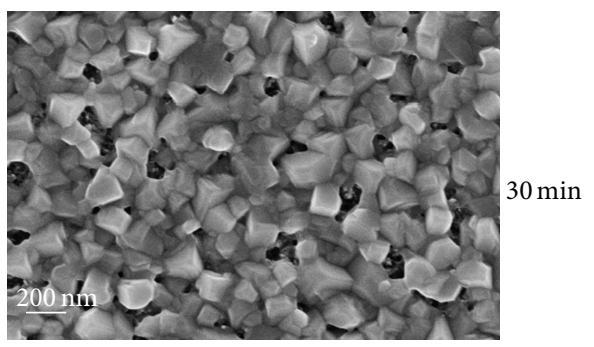

(j)

Figure 7: Top-view SEM images of the $\mathrm{PbI}_{2}$ layer deposited on the $\mathrm{mp}-\mathrm{TiO}_{2}$ coated FTO substrate, where the drying time is for (a) 0 min, (b) $5 \mathrm{~min}$, (c) $10 \mathrm{~min}$, (d) $20 \mathrm{~min}$, and (e) $30 \mathrm{~min}$. The $\mathrm{MAPbI}_{3}$ thin film layers correspond to the $\mathrm{PbI}_{2}$ films (f-j), which were dried at room temperature for different time. 


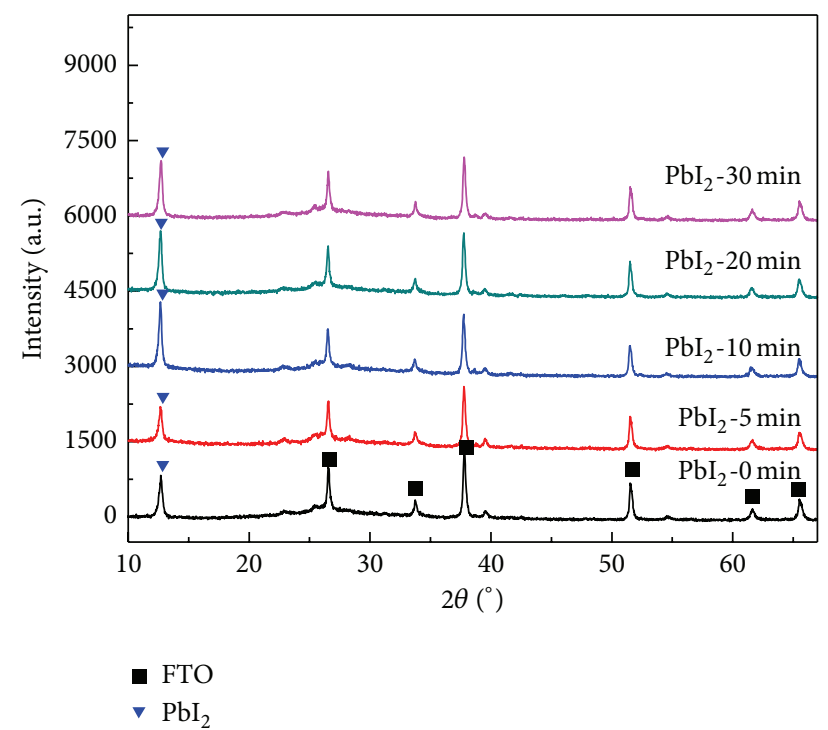

FigURE 8: XRD patterns of $\mathrm{PbI}_{2}$ films, which were dried for different time.

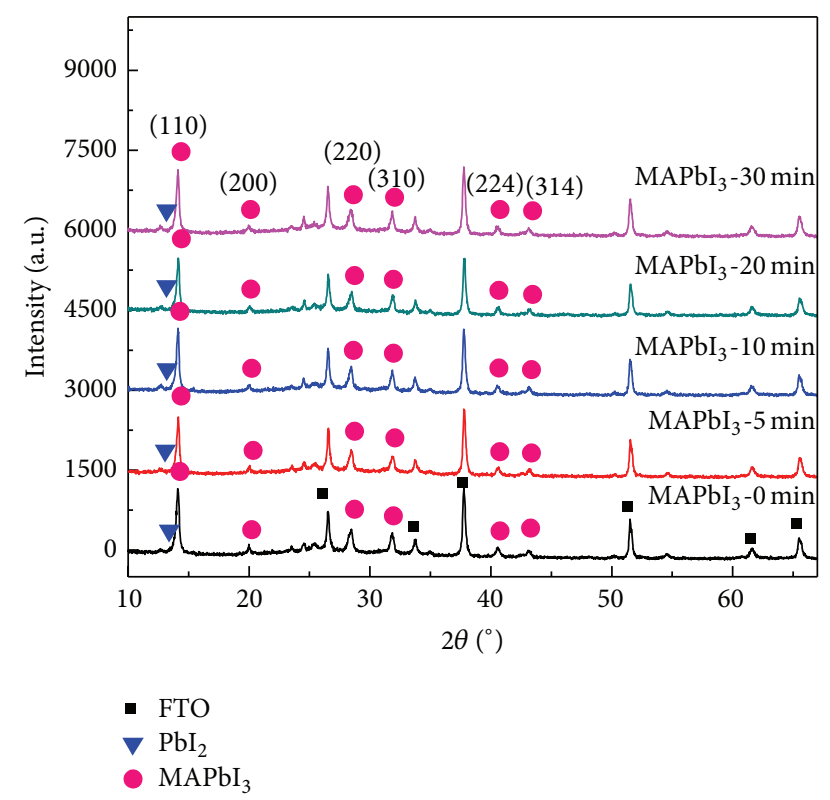

FIGURE 9: XRD patterns of $\mathrm{MAPbI}_{3}$ thin films. The $\mathrm{MAPbI}_{3}$ depended on the $\mathrm{PbI}_{2}$, which is deposited for different drying time.

$\mathrm{PbI}_{2}$. When the preheating substrate temperature is around $70^{\circ} \mathrm{C}$, the best PCE of MPSCs reaches $4.07 \%$. On the basis of the temperature, we researched the drying time which influences the photovoltaic performance of solar cells. We found that the PCE is up to the maximum of $4.23 \%$ for $10 \mathrm{~min}$. Utilizing films fabricated by these two methods, $J_{\mathrm{sc}}$ and PCE have a remarkable improvement. Furthermore, we also tried to analyze the preheating substrate and the drying time to influence the crystallinity and morphology of perovskite films. It was noted that these two methods are beneficial to increasing the crystallinity of perovskite and fabricating the perovskite thin film more uniform and

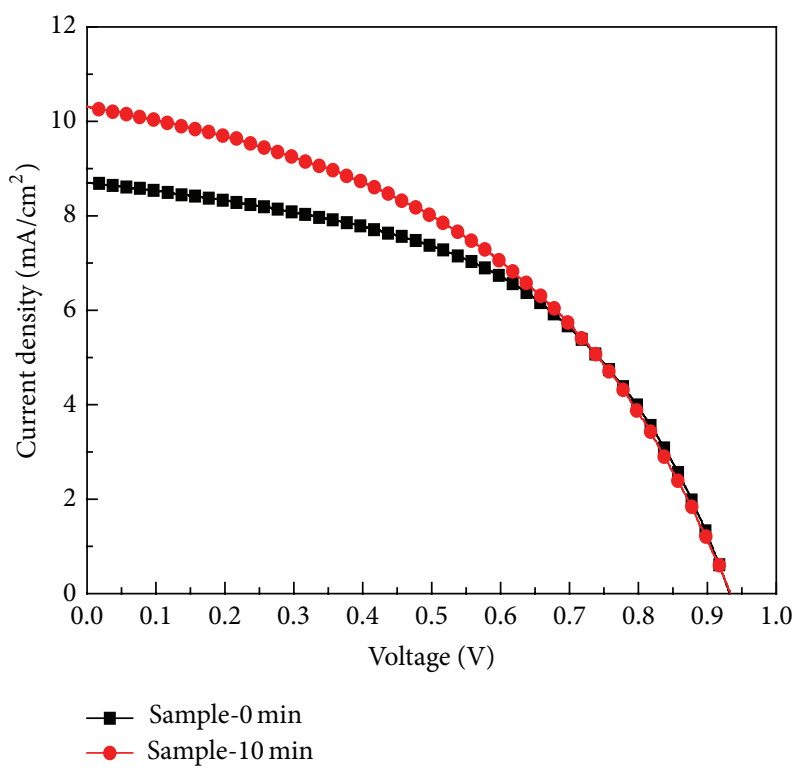

FIgURE 10: $J-V$ characteristic curves of the optimum MPSCs depending on the drying time of 0 min (black) and $10 \mathrm{~min}$ (red).

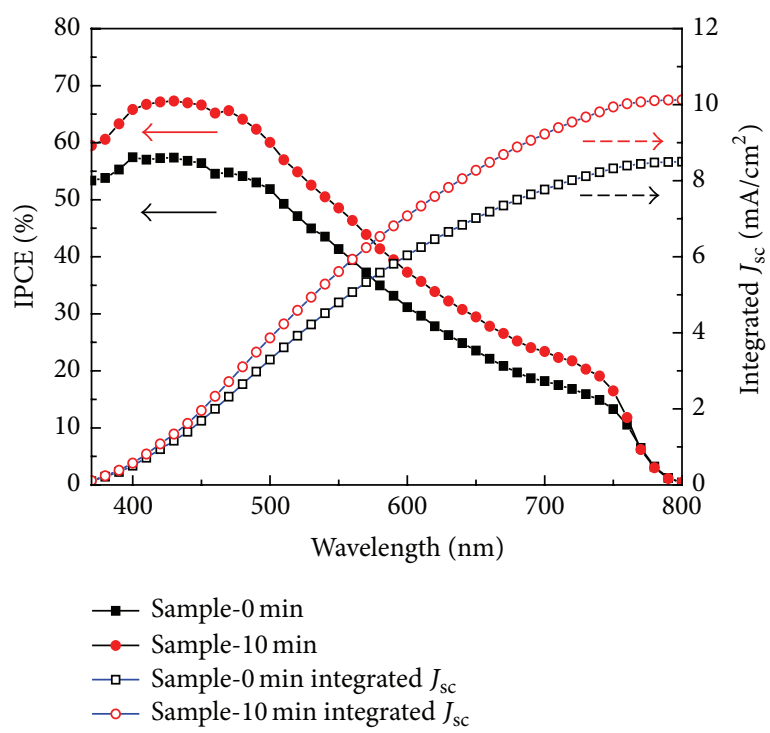

FIGURE 11: The IPCE curves and integrated $J_{\text {sc }}$ curves of MPSCs for $0 \mathrm{~min}$ and $10 \mathrm{~min}$.

denser, so as to improve the efficiency of the solar cells. These two treatment processes have a significant effect on the crystallinity and morphology of perovskite films, in parallel with the perovskite optoelectronic devices, such as perovskite light-emitting diodes, perovskite nanowire lasers, and perovskite photo-detectors.

\section{Competing Interests}

The authors declare that there are no competing interests regarding the publication of this paper. 


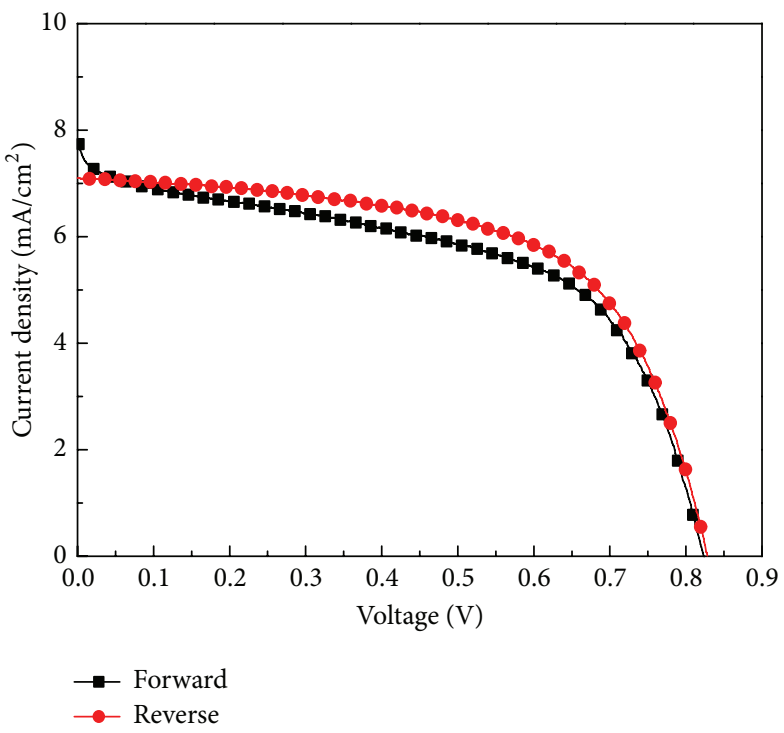

(a)

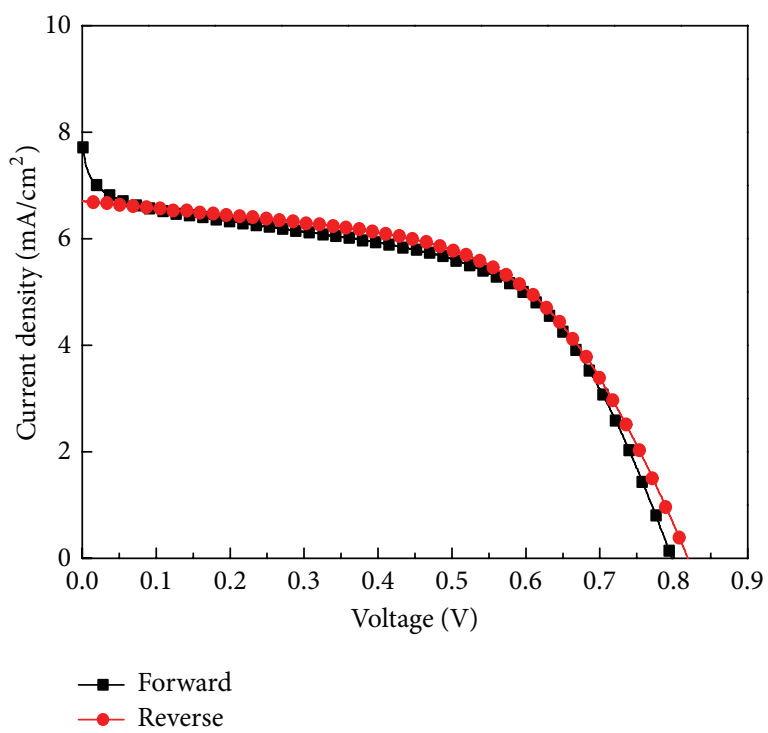

(b)

Figure 12: The typical $J-V$ characteristics of forward and reverse scan of MPSCs with the drying time of (a) 0 min and (b) 10 min. From short circuit to forward bias (black) and from forward bias to short circuit (red) current density-voltage curves are obtained under AM1.5 illumination.

\section{Acknowledgments}

This work was partially supported by Project of Natural Science Foundation of China (91233201 and 61376057), Beijing Key Laboratory for Sensors of BISTU (KF20151077203, KF20151077204, and KF20151077205), and Beijing Key Laboratory for Photo Electrical Measurement of BISTU (GDKF2013005).

\section{References}

[1] H.-S. Kim, C.-R. Lee, J.-H. Im et al., "Lead iodide perovskite sensitized all-solid-state submicron thin film mesoscopic solar cell with efficiency exceeding 9\%," Scientific Reports, vol. 2, no. 8, article 591, 7 pages, 2012.

[2] J. Burschka, N. Pellet, S.-J. Moon et al., "Sequential deposition as a route to high-performance perovskite-sensitized solar cells," Nature, vol. 499, no. 7458, pp. 316-319, 2013.

[3] M. Liu, M. B. Johnston, and H. J. Snaith, "Efficient planar heterojunction perovskite solar cells by vapour deposition," Nature, vol. 501, no. 7467, pp. 395-398, 2013.

[4] Y. Ma, L. Zheng, Y.-H. Chung et al., "A highly efficient mesoscopic solar cell based on $\mathrm{CH}_{3} \mathrm{NH}_{3} \mathrm{PbI}_{3-x} \mathrm{Cl}_{x}$ fabricated via sequential solution deposition," Chemical Communications, vol. 50, no. 83, pp. 12458-12461, 2014.

[5] M. I. Dar, N. Arora, P. Gao, S. Ahmad, M. Grätzel, and M. K. Nazeeruddin, "Investigation regarding the role of chloride in organic-inorganic halide perovskites obtained from chloride containing precursors," Nano Letters, vol. 14, no. 12, pp. 69916996, 2014.

[6] E. Edri, S. Kirmayer, M. Kulbak, G. Hodes, and D. Cahen, "Chloride inclusion and hole transport material doping to improve methyl ammonium lead bromide perovskite-based high open-circuit voltage solar cells," Journal of Physical Chemistry Letters, vol. 5, no. 3, pp. 429-433, 2014.
[7] A. Dualeh, N. Tétreault, T. Moehl, P. Gao, M. K. Nazeeruddin, and M. Grätzel, "Effect of annealing temperature on film morphology of organic-inorganic hybrid pervoskite solid-state solar cells," Advanced Functional Materials, vol. 24, no. 21, pp. 32503258, 2014.

[8] H. Yu, X. Liu, Y. Xia et al., "Room-temperature mixed-solventvapor annealing for high performance perovskite solar cells," Journal of Materials Chemistry A, vol. 4, no. 1, pp. 321-326, 2015.

[9] H.-S. Ko, J.-W. Lee, and N.-G. Park, "15.76\% efficiency perovskite solar cells prepared under high relative humidity: importance of PbI2 morphology in two-step deposition of CH3NH3PbI3," Journal of Materials Chemistry A, vol. 3, no. 16, pp. 8808-8815, 2015.

[10] Z. Wei, K. Yan, H. Chen et al., "Cost-efficient clamping solar cells using candle soot for hole extraction from ambipolar perovskites," Energy and Environmental Science, vol. 7, no. 10, pp. 3326-3333, 2014.

[11] D. Bi, G. Boschloo, S. Schwarzmüller, L. Yang, E. M. J. Johansson, and A. Hagfeldt, "Efficient and stable $\mathrm{CH}_{3} \mathrm{NH}_{3} \mathrm{PbI}_{3}$ sensitized $\mathrm{ZnO}$ nanorod array solid-state solar cells," Nanoscale, vol. 5, no. 23, pp. 11686-11691, 2013.

[12] W. S. Yang, J. H. Noh, N. J. Jeon et al., "High-performance photovoltaic perovskite layers fabricated through intramolecular exchange," Science, vol. 348, no. 6240, pp. 1234-1237, 2015.

[13] Z. Shao, X. Pan, X. Zhang et al., "Influence of structure and morphology of perovskite films on the performance of perovskite solar cells," Acta Chimica Sinica, vol. 73, no. 3, pp. 267-271, 2015 (Chinese). 

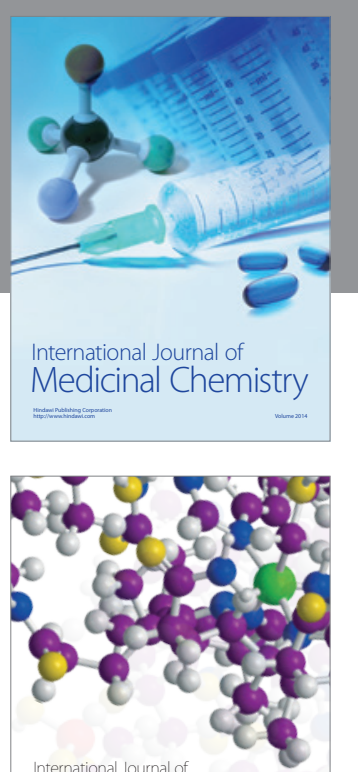

Carbohydrate Chemistry

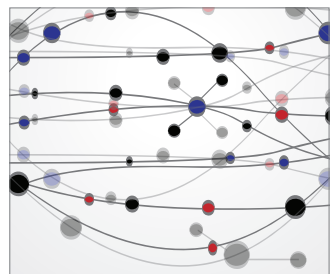

The Scientific World Journal
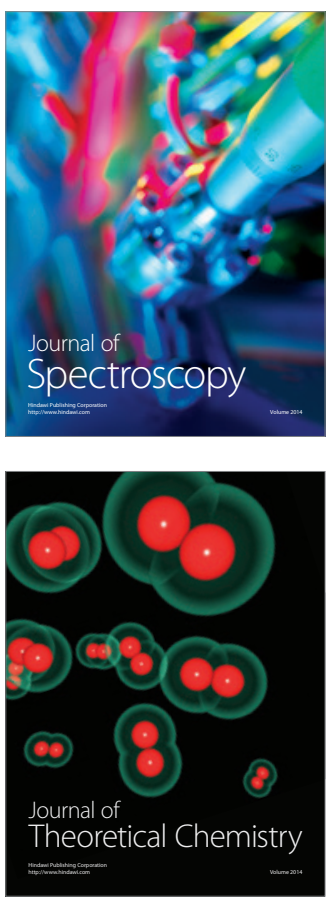
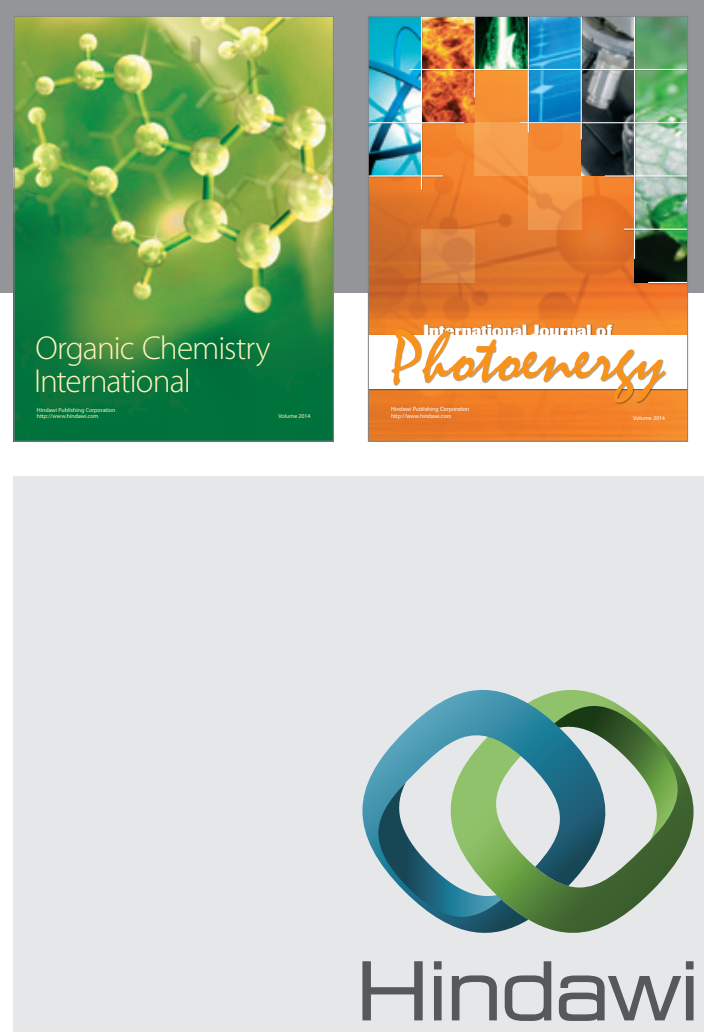

Submit your manuscripts at

http://www.hindawi.com

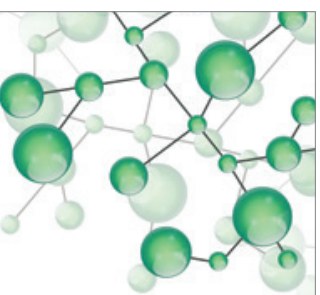

International Journal of

Inorganic Chemistry

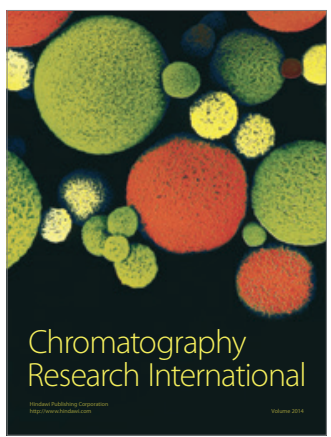

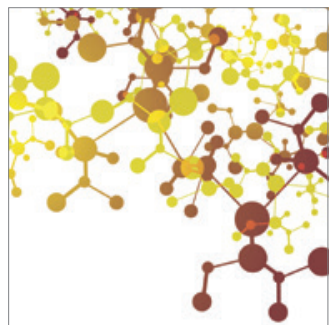

Applied Chemistry
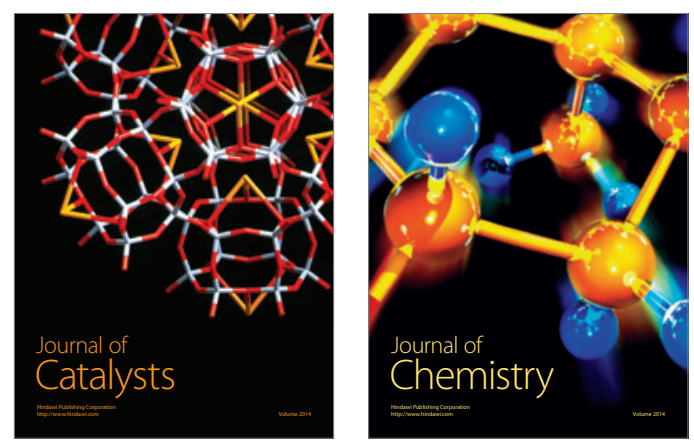
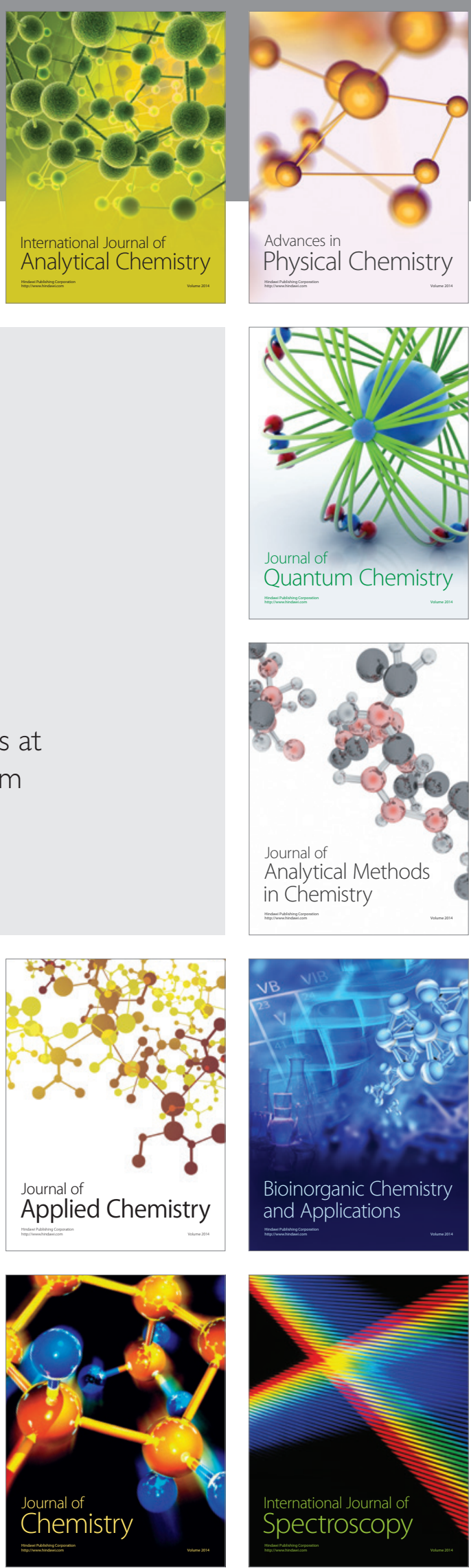